DESCRIPTIONS OF NEW SPECIES OF AUSTRALIAN COLEOPTERA.

Fart xvil.

By Arthur M. Lea, F.E.S.

(One Text-figure.)

NITIDULIDAE.

Cychramus fimbriatus, n. sp.

o. Dull eastaneous-brown, parts of appendages somewhat paler, elub infuscated. Moderately clothed with short, depressed ashen pubescence, interspersed with longer, subdepressed and somewhat reddish hairs; a conspicuous fringe on each side.

Head with dense and sharply-defined but rather small punctures, becoming still smaller on elypeus; labrum deeply incised. Antennae with third joint elongate, club almost circular. Prothorax evenly convex, base about thrice as wide as the median length, sides strongly rounded and very feebly margined, hind angles rounded off, apex about half the width of base, deeply emarginate, the emargination straight across middle, oblique on sides; punctures much as on head. Elytra, when at rest, with outlines continuous with those of prothorax, scarcely longer than the basal width, sides evenly diminishing to apex; punctures as on prothorax, non-striated. Intereoxal process of prosternum truncated posteriorly, middle and hind coxae widely separated. Fifth segment of abdomen notehed at apex, and with a small conical process there, sixth segment small, eireular, and slightly concave. Legs stout, three basal joints of front and middle tarsi wide, of the hind tarsi rather thin. Length, $6.25 \mathrm{~mm}$.

Hab.-Queensland: Cairns (E. Allen), unique.

The marginal fringe is dense and even on each side from apex of prothorax to apex of elytra, but gradually decreases in length from apex to base of prothorax and from base to apex of elytra, it is continued, but more irregularly and with longer hairs to tip of abdomen; it causes the species to be the widest in proportion of all Australian Nitidulidae known to me. On the type, portion of the propygidium is exposed.

\title{
MALACODERMIDAE.
}

Metriorrhynchus hexastichus, n. $\mathrm{sp}$.

6. Sooty-brown; sides of prothorax, and sides and tips of elytra flavous.

Head with very short muzzle. Antennae long and rather thin, moderately 
serrated, all the joints (after the very small second one) longer than wide, third slightly longer than fourth, eleventh about one-fourth longer than tenth. Prothorax almost as long as the apical width, five-areolate, apex obtusely produced in middle, front angles almost rectangular, hind ones produced and acute. Elytra slightly wider near apex than at base; with single rows of large and mostly quadrangular punctures, but becoming double on sides and base. Length, $5.5 \mathrm{~mm}$.

Hab.-New South Wales: Blue Mountains (Dr. E. W. Ferguson); unique.

The dark parts of the type are of a dingy sooty-brown, but probably on fresh specimens would be black; the flavous parts of the elytra are slightly dilated on the shoulders and tips, and continued for a short distance on the suture near apex; the legs and antennae are so thin as to appear semi-transparent. The median areolet of the prothorax is narrow at base, of moderate width in middle, and continued almost to apex; an oblique and moderately sharp costa connects it with the middle of each side. The punctures, except close to the base, are in six rows on each elytron, not in five, as is usual when they are in single series, as the lateral row is doubled throughout its length; at the base there are eight rows on each, owing to the humeral thickening preventing the doubling of the third and fourth series. The elytral punctures in single series on most of the surface, and the bicoloured and five-areolate prothorax, readily distinguish the species from all previously described ones.

\section{MetriorRhynchus sculpticollis, n. $\mathrm{sp}$.}

\$. Black and brick-red verging to flavous.

Head with rostrum rather long (about two-thirds the length of prothorax). Antennae rather long and thin, third joint fully thrice as long as wide, fourth about one-third shorter than third, and slightly longer than fifth, the others to tenth gradually decreasing in length but becoming more strongly serrated, eleventh about one-third longer than tenth. Prothorax slightly longer than the apical width; conspicuously seven-areolate; apex subtriangularly produced but truncated in middle, sides subparallel on apical half, then dilated and elevated to base, with the hind angles rounded off. Elytra almost parallel-sided; with regular double rows of punctures, the alternate interstices moderately elevated. Femora with some moderately long hairs; tibiae rather wide. Length, 8-10.5 mm.

Hab.-Queensland: Cairns (E. Allen).

The pale parts are the prothorax, scutellum, elytra, two spots at base of rostrum, and parts of three or four basal joints of antennae; on the type most of the front femora and less of the middle ones are pale, on a second specimen the legs are almost entirely black. Seen from behind the median areolet, at its widest part, appears to have two short costae, connecting it with one which touches the middle of the apex; so that the three form a long-stemmed $\mathrm{Y}$, but from in front the short arms of the $\mathrm{Y}$ do not appear to quite touch the marginal costae of the areolet at its widest, consequently, although seven areolets are distinct, the medio-basal one, and two medio-apical ones, do not appear to be completely isolated from each other, although distinetly separated from the lateral ones. In general appearance it is close to $M$. elongatus, $M$. uniformis, $M$. textilis, $M$. nigripes and $M$. rufirostris, from all of which it is distinguished by the rostrum, this being decidedly longer than in elongatus and rufirostris, and shorter than in the others; its base is also bimaculate. The front of the prothorax is also distinctive: on both specimens the front half of each of the four frontal 
areolets is occupied by numerous transverse or oblique subcostal elevations, due to narrow striae, and not rising to the level of the costae margining the areolets.

\section{Metriorrhynchus RUFicollis, n. sp.}

๙. Black; prothorax, scutellum, and base of elytra brick-red.

Head without rostrum. Antennae moderately long, third to tenth joints ramose, eleventh more than twice the length of the non-ramose portion of tenth. Prothorax moderately transverse; conspicuously seven-areolate; apex subtriangularly produced in middle, front angles rounded off, hind ones produced and acute. Elytra almost parallel-sided; with double rows of somewhat irregular punctures, the alternate interstices conspicuously elevated. Length ( $\delta$, $\uparrow), 7-7.5$ $\mathrm{mm}$.

9. Differs in having the antennae shorter, wider and strongly serrated, apex of prothorax less produced, abdomen wider, subapical segment not notehed, and legs somewhat shorter.

Hab.-Queensland: Cairns and Little Mulgrave River (H. Hacker).

On the type, the pale portion of the elytra is longest on the shoulders, where it is about twice the length of the scutellum, but it is not the length of the scutellum near that organ; on the female it occupies rather more than the basal fourth; a second female is evidently somewhat discoloured, its pale parts being of a rather dingy flavous, but they cover the same area as on the other; the ramus of the third joint of the male is about half as long again as its supporting joint; on the following joints it increases in length to the seventh, when it decreases to the tenth, the ramus on that one being no longer than its supporting joint. From some directions the elytral punctures at first appear to be in single series, but on eloser examination connecting longitudinal lines are quite distinct. In my table (Trans. Ent. Soc. Lond., 1909, p. 51) it would be placed with $M$. longicornis and $M$. costicollis; from the former it is distinguished by the ramose antennae of the male, and from the latter by the very different elytral punctures, and by each elytron having four conspicuous diseal costae throughout.

\section{METRIORRHYNCHUS LATERARIUS, n. sp.}

§. Prothorax, scutellum and elytra brick-red; trochanters obscurely pale, elsewhere black.

Head with very short rostrum. Antennae with third to tenth joints ramose, eleventh twice the length of non-ramose part of tenth. Prothorax moderately transverse; conspicuously seven-areolate; apex obtusely produced in middle, front angles obtuse, hind ones slightly acute. Elytra narrow; with regular double rows of punctures, the alternate interstices moderately elevated. Length, 7-7.5 $\mathrm{mm}$.

Hab.-Queensland: Cairns (E. Allen).

In my table would be placed with $M$. miniatus, which has the prothorax considerably wider, with the median areolet longer and the front ones much less sharply defined; structurally it is rather close to $M$. gracilis, but with elytra entirely pale, and thickened front margin of prothorax not semidouble; from the specimens of $M$. apicivarius, with entirely pale elytra, it differs in the antennal rami being much shorter, and normally pubescent, instead of hairy; the ramus of the third joint is scarcely longer than its support, that of the tenth joint is no longer, and on not one of the intervening joints is it twice as long as its support. 


\section{Heteromastix obsourus, n. sp. (Text-figs. A, B.)}

๙. Dark chocolate brown, some parts black, parts of legs obscurely paler. Clothed with ashen pubescence.

Head rather large; eyes small. Antennae stout, first joint about twice the length of second but scarcely longer than third, fourth to ninth each slightly longer than wide, tenth and eleventh irregular. Prothorax almost twice as wide as long; margined throughout. Elytra almost parallel-sided throughout; with dense and minute, but usually sharply defined punctures. Subapical segment of abdomen deeply incised. Length, $6 \mathrm{~mm}$.

Hab.-New South Wales: Forbes, unique (H. J. Carter from A. Stephens).

A fairly wide species, readily distinguished from all others with terminal joints of antennae distorted, by its almost uniformly dark-brown colour; the antennae are somewhat thicker than in $H$. gagaticeps, and $H$. flavifrons, and the terminal joints are of different shape. The tenth joint is somewhat wider than the ninth and longer on one side than on the other, the eleventh is about as long as the ninth and tenth combined, produced into a short process at the base on to the shorter side of the tenth, and constricted near the middle.

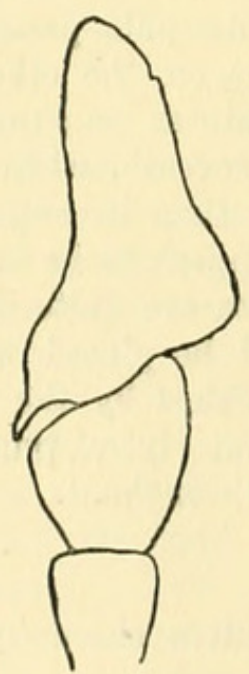

$\Delta$

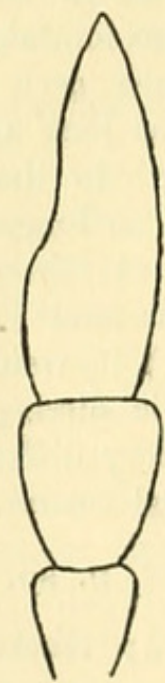

B

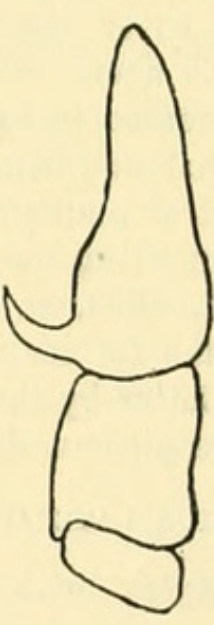

$\mathrm{C}$

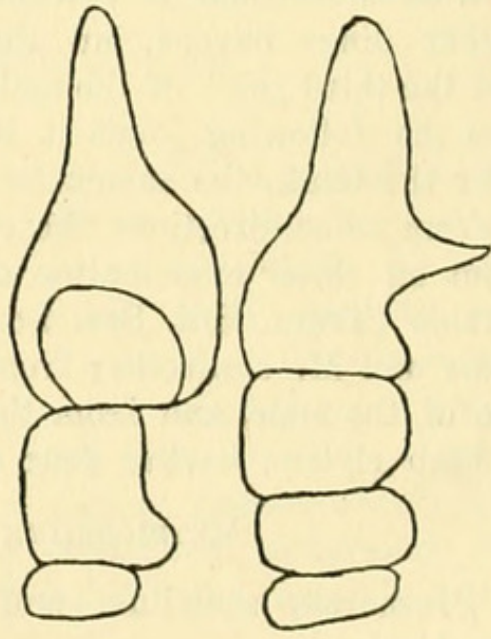

E

A.B. Terminal joints of antennae of Heteromastix obscurus. C.D.E.

,

,

, ,

H. mirus.

\section{Heteromastix mirus, n. sp. (Text-figs. C, D, E.)}

ঠ. Black; muzzle, prothorax, legs (parts of hind and of middle femora infuscated), and antennae (four or five median joints slightly infuseated) flavous. With short, ashen pubescence.

Head obliquely flattened or very gently convex in front, with two feeble inter-ocular impressions. Antennae moderately long, first joint as long as second and third combined, second more than half the length of third, sixth to ninth transverse and slightly produced on one side, tenth and eleventh distorted. Prothorax almost twice as wide as long, sides dilated and slightly thickened near apex. Elytra parallel-sided to near apex; with dense and fine, subrugulose punctures. Length, $3.5 \mathrm{~mm}$. 
Hab.-Queensland: Coen River (H. Hacker's No. 536).

The eleventh joint of antennae near the base has a strong eurved spine marking the end of a large excavation; the tenth joint is longer than the ninth and eighth combined, and also has a large hollow; on one side of the base it is produced so as to embrace the ninth feebly; from some directions it appears as two conspicuous joints, and the antennae in consequence appear to be twelvejointed; from other directions the eleventh also appears to be obliquely divided into two joints; in fact the two apical joints alter in appearance with every point of view. $H$. bicolor has all the joints thinner, and the ninth to eleventh very different.

\section{Heteromastix cribripennis, n. sp.}

๑. Black; tips of elytra, part of under surface of muzzle, and trochanters obseurely pale. With moderately dense, ashen pubescence.

Head with vague inter-ocular impressions; with fairly distinet punetures in front, but not sharply defined. Antennae long and thin, second joint not half the length of third, sixth and seventh each about the length of eleventh, and slightly longer than the intervening ones. Prothorax fully twice as wide as long, margined throughout, sides strongly rounded in front and slightly narrower there than at base; with submarginal punctures. Elytra thin, slightly wider near apex than at base; with erowded and comparatively large, sharply defined punetures. Subapical segment of abdomen deeply notched. Legs long and thin. Length ( $\sigma^{2}$, ९), $4.5-5 \mathrm{~mm}$.

9. Differs in having the head smaller, with less prominent eyes, legs and antennae shorter, and subapical segment of abdomen straight at apex.

Hab.-Tasmania: Waratah, Burnie (A. M. Lea).

Close to H. tenuis, but elytra without purplish gloss, and (on four specimens) tipped with obseure flavous, the sides near base of prothorax hardly notehed (there is a feeble incurvature there, but on the male of tenuis there is a small triangular notch); the pubescence of the elytra is denser, shorter and paler, the antennae are thinner, and the abdominal notch of the male is much longer; from $H$. niger it is still more distinct. In my table (l.c., p. 131) it would be placed with $H$. dolichocephalus, to which it is not at all elose. On one male the abdomen and femora are obscurely paler than the adjacent parts. A male variety from Southport has a flavous, almost white, vitta from base to apex of each elytron, near the side, but dilated so as to cover the entire apex for a short distance.

\section{Heteromastix megalops, n. sp.}

ð. Prothorax, seutellum and legs flavous, elsewhere more or less deeply infuscated. With short, ashen pubescence.

Head large, gently concave in front. Eyes unusually large and prominent. Antennae long and thin, extending almost to tips of elytra. Prothorax more than twice as wide as long, base and apex finely margined; sides suddenly and strongly dilated, or obtusely dentate, slightly nearer apex than base. Elytra parallel-sided to near apex; with dense, and fine, rugulose punctures. Length ( $\left.\sigma^{*}, \uparrow\right), 2.75-3 \mathrm{~mm}$.

ๆ. Differs in having the head smaller, eyes smaller (but still of large size), antennae much shorter, and in the abdomen.

Hab.-Queensland: Cairns (E. Allen).

The elytra of the type could not be regarded as black, they are of a dark smoky-brown, similar in shade to most of the under surface (the tip of the 
abdomen is paler); the head is moderately infuscated on the basal half and paler in front, but the shades of colour are not sharply defined; the antennae are almost uniformly infuseated throughout. One female has the head uniformly infuscated, but otherwise its colours are as those of the type; a second female has the head entirely pale, and elytra much less deeply infuscated. Regarding the head as pale the species, in my table, would be associated with $H$. anticus and $H$. geniculatus, which have sides of prothorax very different and much smaller eyes; regarding the head as dark it would go with the allies of $H$. pusillus, from all of which it is at once distinguished by the very large eyes; thus on the male of $H$. pusillus the combined width of both eyes is less than half the width of the intervening space, on the present species each eye is more than half the width of that space, and its length is about equal to the combined lengths of the second and third joints of antennae; the sides of the prothorax are much as in $\mathrm{H}$. denticollis and $H$. angustus, whose eyes are much smaller.

\section{Hypattalus Cribripennis, n. sp.}

ð. Black; labrum, prothorax, parts of under surface of three basal joints of antennae, and trochanters flavous. Moderately clothed with short, erect, dark hairs, and with sparse, ashen pubescence.

Head gently convex, slightly depressed in front. Antennae rather long, third to tenth joints obtusely serrated, seventh joint slightly longer than the adjacent ones, and about equal to eleventh. Prothorax widely transverse, sides widely rounded and with the base obliquely margined, a shallow depression near base, and a still more feeble one near apex; with a few scattered punctures. Elytra parallel-sided to near apex, sides and suture slightly thickened, the apex more distinctly so; with erowded, sharply defined punctures, a few of which are confluent. Legs moderately long. Length $\left(\delta^{*}\right.$, $), 5-5.75 \mathrm{~mm}$.

9. Differs in having the head smaller, with two feeble foveae in front, eyes smaller and less prominent, antennae shorter and less strongly serrated, apical joint of palpi smaller, apex of elytra searcely thickened, legs somewhat shorter, and elothing of upper surface sparser.

Hab.-Tasmania: Waratah (A. M. Lea).

At first glance much like many species of Heteromastix but with exsertile vesicles. In my table (l.c., p. 169) would be placed with H. abdominalis, which is a much smaller species, with blue elytra, ete.; H. longicornis has bluish elytra and much longer and less strongly serrated antennae; the female in general appearance is somewhat like a large female of $H$. trianguliferus, but the antennae are less strongly serrated, and more of the head is dark. A female, from Mount Wellington, probably belongs to this species, but has the frontal foveae more conspicuous, and elytra with a faint purplish gloss.

Hypattalus apiciventris, n. sp.

§. Black; muzzle, parts of four or five basal joints of antennae, basal joints of palpi, prothorax, and base of femora flavous. With sparse and minute, ashen pubescence.

Head moderately convex between eyes, slightly irregularly concave in front; with small, scattered punctures, becoming denser at base. Antennae moderately long and feebly serrated, second joint small, third and fourth not much larger. Prothorax strongly transverse, base finely margined, basal half 
of sides more widely so; with a few scattered punctures. Elytra parallel-sided to near apex, sides and suture searcely thickened; with dense and sharply defined, but somewhat rugose punctures. Apical segment of abdomen rather large. Hind tibiae rather thin and strongly eurved. Length, 4-4.5 mm.

Hab.-Tasmania: Waratah (A. M. Lea).

Close to the preceding species, but antennae shorter and less serrated, more of muzzle and of legs pale, elytra with much sparser elothing, and with sparser, although dense, punctures. The elytra have a faint bluish gloss, and their sides in the middle are very narrowly and obseurely flavous. The apical segment of the abdomen is large and less liable to contraction than the others, as it is gently convex and without wrinkles on the three specimens before me, its dorsal and ventral sclerites meet at the tip, and, from the sides, a passage may be seen through them.

\section{Hypattalus flavipes, n. sp.}

ð. Black; prothorax and legs flavous, parts of tarsi infuscated. With short, ashen pubescence.

Head feebly convex between eyes, with two shallow depressions in front; with small and sparse punctures, becoming denser about base. Antennae moderately long, thin and feebly serrated. Prothorax strongly transverse, sides and base finely margined; with sparse, inconspicuous punetures. Elytra parallelsided to near apex, sides and suture scarcely thickened; with erowded, sharply defined punctures. Hind tibiae rather strongly curved. Length, $3 \mathrm{~mm}$.

Hab.-New South Wales: National Park (A. M. Lea).

Like $H$. longicornis on a small scale, but upper surface almost glabrous, elytral punctures more sharply defined, legs flavous and antennae somewhat shorter; in my table it would be placed with $H$. abdominalis, but is thinner, differently coloured, antennae much longer and elytral punctures larger. Parts of the basal joints of antennae are obscurely flavous or testaceous, and the space between the eyes is obscurely diluted with red.

\section{Hypattalus parvoniger, n. sp.}

9. Black; trochanters, most of front legs, parts of the others and parts of four or five basal joints of antennae flavous or testaceous. Upper surface with sparse and extremely short, ashen pubescence.

Head with two shallow depressions in front; punctures sparse and minute. Antennae moderately long and obtusely serrated, eleventh joint about twice the length of tenth. Prothorax rather strongly transverse, sides and base finely margined, a shallow depression each side of base; punctures minute on sides, not traceable elsewhere. Elytra slightly dilated to near apex, sides and suture scarcely thickened, with small rugulose punctures. Legs thin, the hind tibiae moderately long. Length, $1.5 \mathrm{~mm}$.

Hab.-New South Wales: Sydney (G. E. Bryant), Eden (H. J. Carter).

Smaller than any other known species, except H. minutus, and upper surface entirely black (in some lights the elytra have a vague purplish gloss); from $H$. carteri it differs in being smaller, elytra darker and non-metallic, legs partly pale, and upper surface almost glabrous. There are fairly numerous punctures on the elytra, and they are sufficiently distinct from oblique directions, but they are nowhere dense and sharply defined. 


\section{Carphurus spinipennis, n. sp.}

ð. Flavous; mesosternum, metasternum, base (but not sides) of several segments of abdomen, and parts of coxae and of femora black; apical half of antennae and parts of tarsi infuscated. With long, dark hairs, and in parts with sparse, white pubescence.

Head with a wide and fairly deep impression in middle; between it and eyes with dense and sharply defined punctures; base transversely strigose. Antennae moderately long, third to fifth joints rather wide, the others gradually decreasing in width. Prothorax slightly longer than its greatest width, a wide shallow depression near base; a few punctures seattered about. Elytra about twice the length of prothorax, each side near apex with a conspicuous notch, its posterior end with a rather long acute spine, directed forwards and outwards; with fairly dense but not very sharply defined punctures. Basal joint of front tarsi with a small, black, inner comb. Length, $4.5 \mathrm{~mm}$.

Hab.-Queensland: Dalby (Mrs. F. H. Hobler), unique.

The armature of the elytra is much as in $C$. cristatifrons and $C$. gallinaceus, but the surface near it is not thickened, and the head is not crested; in $C$. pisoniae the head is bimaculate, and very differently seulptured, the elytral punetures are much stronger, and the side of each elytron before the spine is abruptly pointed, in the present species the side is gently curved to the spine.

\section{Carphurus nigrofasciatus, n. sp.}

§. Black and flavous. With moderately long, dark hairs, seattered about, and in parts with sparse, whitish pubescence.

Head gently convex between eyes; with a large, obtuse, inter-antennary elevation, its posterior end bounded by a narrow groove; with dense and small punctures, the extreme base transversely strigose. Antennae moderately long, second joint distinctly transverse, the whole of its inner side slightly produced. Prothorax about once and one-third as long as wide, apex not much wider than base, a large shallow depression near base; with dense and small punctures on sides, much sparser elsewhere. Elytra slightly dilated to beyond the middle, at apex widely separately rounded; with numerous small, and rather sharply defined, but sub-asperate punctures. Basal joint of front tarsi lopsided, with a black inner comb. Length, $4 \mathrm{~mm}$.

Hab.-Queensland: Dalby (Mrs. F. H. Hobler), unique.

At first glance the type appears to be a variety of $C$. elongatus, but the sculpture of the head and the dilated second joint of antennae are at once distinctive. In my table (l.c., p. 188) it could not be referred to $g g g$ as the elytra have less than half of their surface black, but the markings are as sharp as in $C^{\prime}$. elongatus. The paler parts are rather dingy and vary from flavous to reddishflavous; they are the head (except for a large subtriangular black spot at the base), prothorax (except for a black spot extending from the apex to the middle on each side), elytra (except for a black fascia near the apex, the fascia covering about one-fourth of their length), parts of two apical segments of abdomen, four basal joints of antennae, and most of legs.

\section{Carphurus collaris, n. sp.}

9. Black, with a slight bluish gloss; elytra metallie violet-blue, prothorax, tibiae and most of basal joint of antennae flavous. With rather sparse, dark hairs, and in places very sparse, whitish pubescence. 
Head with a vague, curved depression, with irregularly distributed punctures. Antennae rather short, third to tenth joints strongly serrated. Prothorax about as long as the greatest width (almost across exact middle), angles rounded off, base no narrower than apex, a very shallow depression near base, with a few seattered punctures. Elytra about thrice the length of prothorax, with dense, rugose punctures. Length, $4.5 \mathrm{~mm}$.

Hab.-Western Australia: Mullewa (Miss J. F. May), unique.

The elytral punctures, although of fairly large size, are so rugose that very few are sharply defined. At first glance the species seems close to C. bifoveatus, but the elytra are of a brighter and more metallic blue, and with the punctures more coarsely rugose; there are also differences of colour in the abdomen and legs. In my table it would be placed with $C$. rhagonychinus, $C$. simulator, and part of $C$. variipennis, but rhagonychinus is now known to be a Balanophorus, which the present species certainly is not, as its front tarsi are combless, and they are comb-bearing in both sexes of that genus; the other species are very differently coloured and punctured.

\section{Carphurus opacipennis, n. sp.}

6. Of a dingy flavous; tip of eleventh joint of antennae, a rather large spot on each elytron, mesosternum, metasternum, parts of under surface of four basal segments of abdomen, and hind coxae infuscated or black. With very short, whitish pubescence; a few long hairs seattered about, but not on prothorax and elytra.

Head rather long, gently convex between eyes, somewhat uneven in front; with minute punctures, becoming more distinct behind eyes; base transversely strigose. Antennae long and thin, very feebly serrated. Prothorax distinctly longer than wide; sides strongly rounded and widest at apical third, a shallow depression near base; punctures inconspicuous. Elytra opaque, about twice the length of prothorax, with erowded but sharply defined punctures. Basal joint of front tarsi large, lopsided, with a narrow black comb on inner edge from near base to apex, around which it curves. Length, $6.5 \mathrm{~mm}$.

Hab.-Queensland: Claudie River (Jas. A. Kershaw). Type (unique) in National Museum.

The elytra are of a darker shade of colour than the other parts, the large spot on each is somewhat rounded, nearer the side than the suture, and at about the apical third; the shoulders are also slightly infuscated; their opaque surface, with dense punctures, causing the surface to appear finely granulated or shagreened, render the species a very distinct one. In my table it would be associated with $C$. frenchi, with which it has few details in common.

\section{Helcogaster obliquiceps Lea.}

A male of this species, from Jenolan (New South Wales) differs from the type in having the head almost entirely dark, the muzzle being, at most, obscurely diluted with red on the sides; the dark parts are also more intensely black than on the type.

\section{Helcogaster maculiceps Lea.}

A male of this species in Mr. H. J. Carter's collection, from Illawarra, has a small black spot on the dise of the prothorax, five of the abdominal segments black except at the tips and sides, and all the femora black on the basal half. 


\section{Helcogaster basirufus Lea.}

Three females, from Geraldton (Western Australia) evidently belong to this species, they differ from the male in having more of the head dark, and without conspicuous ridges and excavations, the prothorax is not notched in front, and the black mark is reduced to a small longitudinal spot; the front tarsi are also simple.

\section{Helcogaster rhyticephalus Lea.}

A female of this species, from Narara (New South Wales) in Dr. Ferguson's collection, has an elongate-oblong black spot on the dise of the pronotum.

\section{Helcogaster nigriventris, n. sp.}

๙. Flavous; mesosternum, metasternum, abdomen, coxae and parts of hind femora black; parts of antennae infuscated. With sparse, dark hairs.

Head with a rather shallow impression each side in front. Antennae rather short and wide, second-tenth joints obtusely serrated. Prothorax moderately transverse, deeply transversely impressed near apex, middle of apex notched, with a small elevation each side of the noteh, hind margin of impression irregular; a shallow depression near base. Elytra distinetly longer than wide; with sparse, inconspicuous punctures. Basal joint of front tarsi large, with a small, black comb. Length, $2.5 \mathrm{~mm}$.

Hab.-Queensland: Herberton, in February (C. J. Wild); unique.

The apical portion of the prothorax is deeply sculptured, but not as in $H$. imperator, from which it also differs in the colour and seulpture of head, entirely pale elytra, ete.; $H$. incisicollis has a deep medio-apical noteh, but the prothorax is otherwise normal; $H$. spinicollis has a simple spine.

\section{Helcogaster ceraticeps, n. sp.}

๙. Black; head, prothorax, four basal joints of antennae and legs flavousred. With numerous long, dark hairs on sides, sparser elsewhere.

Head wide, with a large, deep, irregular, transverse, inter-ocular excavation, with two small tubercles in front, and a larger one close to each eye; base with dense punctures. Antennae moderately long. Prothorax distinctly transverse, sides rather strongly rounded, a shallow open depression near base. Elytra short and almost impunctate. Basal joint of front tarsi with a small black comb at inner apex. Length ( $\delta$, $\uparrow), 3.5-4 \mathrm{~mm}$.

+. Differs in having the head opaque and densely punctate, and without excavation or tubereles, antennae thinner, abdomen wider, and front tarsi combless.

Hab.-Vietoria: Sea Lake (J. C. Goudie's No. 828).

A very distinet species nearer $H$. major than any previously deseribed species, but narrower, excavation of head of male somewhat different, the tubercle near each eye more prominent, antennae thinner, much less strongly serrated and mostly dark (a few of the joints beyond the fourth are obseurely diluted with red, but the apical ones are black), elytra shorter and comb of tarsi much smaller. H. coelocephalus, H. hoplocephalus, and H. aterrimus are much smaller species, and very differently coloured. The head when viewed from behind is seen to have four tubercles: two small conical ones in front, and a larger and somewhat curved one, projecting like a horn above each eye. The posterior margin of the exeavation is almost straight, but its anterior one is irregular. 


\section{Helcogaster convexiceps, n. sp.}

o. Flavous; apical three-fourths of elytra, metasternum, and six apical joints of antennae black. With sparse, dark hairs.

Head rather strongly and evenly convex; with numerous small, and rather distinct punctures. Antennae longer than usual, none of the joints transverse. Prothorax with sides narrowed to base; a rather large, transverse, elosed, subbasal depression; with fairly distinct punctures scattered about. Elytra moderately long; with numerous very minute, rugulose punctures. Basal joint of front tarsi with a small black comb. Length, $2.25 \mathrm{~mm}$.

Hab.-New South Wales: Illawarra, one specimen in October (G. E. Bryant).

The head rather strongly convex, nonexeavated, and with distinct punctures, distinguishes from $H$. trisinuatus, the absence of a frontal tubercle from $H$. humeralis and $H$. seminigripennis, and the very different prothorax from $H$. thoracicus. In my table (l.c., p. 216) it would be associated with H. simpliciceps, whose head is much less convex, abdomen black, and pale portion of elytra continued along sides.

\section{CHRYSOMELIDAE.}

\section{Macrogonus ventralis, n. sp.}

Flavous; head (except base and muzzle), scutellum, elytra, abdomen (except part of basal segment), tarsi, and most of tibiae dark metallie green, with a more or less distinct purplish gloss, a fairly wide median vitta on prothorax, and an oblique spot or vitta towards each side also greenish, five basal joints of antennae shining purple, the others opaque purple; tip of mandibles and apical joint of palpi infuscated.

Head with a triangular inter-ocular impression, connected with the base by a median line; punctures rather sparse and small, a few larger ones near eyes. Antennae long, extending to about middle of abdomen. Prothorax about onethird wider than median length, all angles slightly armed, apex slightly wider than base, and slightly incurved at middle, sides gently rounded in middle; with sparse and rather small punctures about middle, becoming larger on sides, but all sharply defined. Scutellum long and triangular. Elytra much wider than prothorax, each with three shallow depressions or foveae, triangularly placed: one on the side at the basal fourth, one half-way between it and suture, the other equidistant from the two front ones; with rows of punctures of moderate size near base, becoming smaller posteriorly; interstices each with a row of very small punctures. Length, $8 \mathrm{~mm}$.

Hab.-New South Wales: Comboyne (W. H. Muldoon), unique.

The type is evidently a female; it is too close to the female of $M$. bifoveicollis to be regarded as other than a Macrogonus, but possibly with other species of that genus may eventually be transferred to Macrolema. The prothorax is nonfoveate, but there is a vague depression on each side of the base. The oblique vittae on the prothorax appear to be hardly more than stains, each extends from near the middle of the apex to near the middle of the side; on each side near the apex, and invisible from above, there is also a stainlike spot; although the elytra are dark green, the colour alters with the point of view to dark blue, and then to purple. 


\section{EROTYLIDAE.}

\section{Episcaphula tetrasticta, n. sp.}

Metallic purple; elytra with four flavous spots, under surface except sides of prosternum, palpi and parts of legs reddish-flavous, rest of legs and antennae blackish, but in places obscurely diluted with red.

Head with distinct but not very large or dense punctures, becoming smaller and denser on clypeus. Third joint of antennae more than twice the length of fourth. Prothorax more than twice as wide as long, sides diminishing in width from base, front angles produced but not very acute; punctures somewhat smaller and sparser than on head; submarginal line deep. Elytra slightly dilated from shoulders to about basal fourth, and then narrowed to apex; with rows of distinct, but not very large punctures, the interspaces with much smaller ones. Abdomen with coxal lines traceable to apex of basal segment, but rather faint posteriorly. Length, 5.75-6 $\mathrm{mm}$.

Hab.-Queensland: Cairns (E. Allen).

A small, rather wide species, allied to E. inchusa, but smaller and elytra with four isolated, pale spots, placed as in the angles of a square: two basal and two median, each of the latter occupies the space between about six lines of punctures, each of the former between about four.

\section{ThaLlis Basipennis, n. sp.}

Chocolate-brown; elytra, under surface, legs and palpi paler. Densely elothed with pale pubescence, becoming conspicuously golden on base of elytra.

Head with erowded punctures of moderate size. Antennae with third joint about once and one-half the length of second; club not very large. Apical joint of each palpus searcely larger than basal joint of antennae, and not securiform. Prothorax about once and one-fourth as wide as long, apex widely truncated, searcely notched near each side, sides gently rounded, front angles scarcely produced, the hind ones acute; with erowded but not very large punctures, many of which are slightly confluent longitudinally. Elytra no wider than prothorax, and searcely twice its length; with regular rows of punctures in distinet striae, interstices gently eonvex, separately narrowly elevated at base, with dense punctures. Prosternum with intereoxal process narrow, its hind end truncated. Coxal lines of abdomen faintly traceable to apex of basal segment. Length, 4.5-5 mm.

Hab.-North Western Australia: Upper Ord River (R. Helms).

The elytra appear to be fasciate at base, the fascia interrupted at suture, but this appearance is really due to the bright golden pubescence there; at the base they are very narrowly elevated, and the scutellum is elevated in the same line. Owing to the convexity of the pronotum the impressed line on each side is only visible at base and apex from directly above. One specimen has the elytra no paler than the prothorax, and the basal fascia of pubescence hardly golden. The species may be eventually transferred to a new genus, as the base of its elytra and apical joint of each palpus are aberrant.

\section{Euxestus ventralis, n. sp.}

Black; head, apex of elytra, and epipleurae obscurely reddish, legs, antennae and palpi castaneo-flavous. Glabrous.

Head with dense and small but sharply defined punctures, a small fovea on each side of clypeus. Antennae short, basal joint large, elub slightly wider than 
long. Prothorax at base about thrice as wide as the median length, base bisinuate, apex gently incurved to middle, margins very narrow; punctures rather dense and small, but sharply defined. Elytra with outlines continuous with those of prothorax, widest at about basal fourth; with dense and moderately strong punctures, more or less seriate in arrangement. Abdomen with coxal lines distinct, and marking the outer edge of a plate, on each side of which the punctures are larger than elsewhere. Length, 2.25-2.75 mm.

Hab.-New South Wales: Forest Reefs (A. M. Lea).

An evenly elliptic, moderately convex species, with the general outlines of mainland specimens of $E$. tasmaniae, but elytra with rather dense punctures, many of which are in regular lines, but not in impressed striae, whereas on that species the striation is conspicuous and the punctures much less in evidence; on the pronotum, however, the punctures are alike on both species. Structurally it is extremely close to and is certainly congeneric with the New Zealand Triplax brouni Pasc., but with stronger punctures and slightly different antennae, at first glance the two species appear to be identical. There are twelve specimens of the typical form before me.

VAR. I. Six specimens from Forest Reefs (Lea), and one from Blue Mountains (Dr. E. W. Ferguson), differ in having an obscurely reddish fascia (interrupted at the suture) at the base of the elytra, more of the apex reddish, and the under surface reddish but with the metasternum infuseated. Compared with $E$. bivulneratus these specimens differ in being narrower and less convex, in having the basal markings more obscure, more of the apex reddish, the punctures much stronger, and the coxal lines more distinet.

\section{Euxestus ater, n. sp.}

Black; parts of under surface obscurely diluted with red, legs antennae and palpi castaneous. Glabrous.

Head with small but sharply defined punctures; a small fovea on each side of clypeus. Antennae short, basal joint large; elub slightly wider than long. Prothorax not thrice as wide as long, base bisinuate and much wider than apex, the latter gently incurved to middle, sides very finely margined; punctures sparse and small. Elytra with sparse and small punctures, some of which appear to be in feeble lines towards base. Abdomen with coxal lines enclosing a distinct plate on each side. Length, 2-2.25 mm.

Hab.-Queensland: Brisbane (A. J. Coates).

The outlines are intermediate between those of $E$. bivulneratus and $E$. ventralis; from the former it is also distinguished by the absence of basal markings on the elytra, from the latter by the considerably smaller and sparser punctures; it is slightly more convex than E. medioniger. The muzzle is not as dark as the base of the head, but at first glance the whole of the upper surface appears to be of a polished black; the joints preceding the club are slightly darker than the rest of the antennae, but this appears to be the case with most species of the genus.

Euxestus atropolitus, n. sp.

Black, highly polished; legs antennae and palpi castaneous, tips of elytra obscurely diluted with red.

Head with sparse and minute punctures, sharply defined only on clypeus. Antennae short, club slightly wider than long. Prothorax about thrice as wide at base as the median length, apex gently incurved to middle, sides and base very 
narrowly margined. Elytra with outlines continuous with those of prothorax, widest at about basal third. Abdomen with coxal lines enclosing a distinet plate on each side. Length, $1.75 \mathrm{~mm}$.

Hab.-New South Wales: Tamworth, Clarence River (A. M. Lea).

Much the size and shape of E. vulneratus, but upper surface entirely black except for the tips of elytra. Under a hand-lens the prothorax and elytra appear to be impunctate.

VAR. ?. Two specimens from the Nepean River (A. J. Coates), and Clarence River (Lea), are possibly varieties of this species, they are of a livid-brown colour with a large infuseate blotch on the elytra, and another on the metasternum, both blotches quite conspicuous, although not sharply limited.

\section{Diphyllus flavonotatus, n. sp.}

Black, apical third of elytra and six spots across the middle flavous, legs, antennae, and palpi flavo-testaceous. Densely clothed with short, suberect pubescence, varying in colour with the derm.

Head with small and crowded punctures. Antennae searcely passing base of prothorax; club two-jointed. Prothorax more than thrice as wide as long, with a sharply defined stria near each side, and a less distinct one near it; punctures much as on head, except on sides, where they are somewhat larger. Elytra with outlines continuous with those of prothorax; with regular rows of punetures, fairly large at base, becoming smaller posteriorly; interstices with small, partially concealed punctures. Length, $2 \mathrm{~mm}$.

Hab.-New South Wales: Ourimbah (A. M. Lea). Unique.

An evenly elliptic species, shorter and more compact than D. ornatellus, and elytral markings very different; the spots across the middle are not in a straight line, but so placed that the median one on each elytron is slightly posterior to the others; the pale apical portion is triangularly advanced on the suture.

\section{Diplocoelus xanthorRhoeae, n. sp.}

Reddish-brown or eastaneous, appendages not much paler. Densely clothed with short, depressed, greyish pubescence, the upper surface in addition with rows of short, semi-erect setae.

Head with small and dense punctures. Antennae short, club three-jointed. Prothorax slightly more than twice as wide as long, sides gently rounded, front angles scarcely produced, with (excluding the margins) ten slightly elevated, parallel lines, of which the four median ones are, except for their clothing, scarcely traceable; punctures much as on head, but slightly larger towards sides. Elytra parallel-sided to near apex, the width of widest part of prothorax; with regular rows of punctures of moderate size, becoming smaller towards suture; interstices with small punctures. Length, 2.75-3.25 mm.

Hab.-Western Australia: Swan River, Darling Ranges; New South Wales: Sydney; Tasmania: Huon River (A: M. Lea).

The species may be taken at the bases of the leaves of several species of Xanthorrhoea. It is allied to D. opacior (specimens of which have also been taken on species of Xanthorrhoea), but is larger, paler, and the prothoracic lines of clothing are much more evident; D. punctatus has the prothorax with much coarser punctures and lines of pubescence scarcely evident, although with distinct grooves; D. latus is wider, with coarser punctures, ete.; D. decemlineatus has median line of prothorax distinct, and elytra not parallel-sided; $D$. dilataticollis 
has middle of prothorax wider than elytra. The smallest specimen is but slightly more than an English line in length, and as the ninth joint of its antennae is only moderately narrower than the tenth the species is evidently allied to $D$. exiguus, from the description of which it differs in having the prothoracic punctures dense and fine (larger on the sides than in the middle), and elytral punctures also evidently much smaller. The larger specimens are slightly wider in proportion than the smaller ones, and the median elevations of the prothorax are even less distinet.

\section{Diplocoelus apicicollis, n. $\mathrm{sp}$.}

Castaneous, appendages slightly paler. Moderately densely clothed with short, depressed, greyish pubescence, upper surface in addition with short, semierect setae.

Head with dense punctures of moderate size; a shallow depression on each side of elypeus. Antennae short, ninth joint slightly larger than eighth but much smaller than tenth, the latter wider than eleventh. Prothorax not twice as wide as long, sides obliquely increasing in width to apex, front angles sharply defined and not produced, the hind ones gently rounded off, with three more or less distinctly impressed lines towards each side; punctures somewhat irregular, but mostly well defined. Elytra parallel-sided to near apex, with rows of fairly large punctures, becoming smaller posteriorly; interstices with small punctures. Length, 2.5-2.75 mm.

Hab.-Western Australia: Swan River (J. Clark and A. M. Lea), Donnybrook (Lea).

Of the size and general appearance of $D$. angustulus, but with front of prothorax decidedly wider; when seen from above the front angles appear to be quite sharply angulate, but on that species, from a similar point of view, they appear to be gently rounded off; the head of the present species is also more transverse. At first glance the club appears to be but two-jointed, and perhaps should really be so considered, but the ninth joint is certainly wider than the eighth.

\section{ENDOMYCHIDAE.}

Stenotarsus parallelus, $n$. sp.

Flavous-red; head, base of prothorax, scutellum, two large spots on elytra, antennae, femora, and tibiae black. Moderately densely elothed with pale, semierect pubescence.

Head with numerous small but distinct punctures; a shallow depression near each eye. Antennae rather short; elub stout. Prothorax with front angles produced and rounded, sides almost parallel elsewhere, sublateral striae deep, becoming foveate at base; with numerous small but sharply defined punctures, becoming larger and denser on sides. Elytra long, parallel-sided to near apex; with rows of rather large punctures, becoming smaller towards suture and posteriorly; interstices with small punctures. Length, 2.75-3.25 mm.

Hab.-New South Wales (Dr. E. W. Ferguson), Sydney (H. J. Carter and A. M. Lea), Gosford (Carter).

The elytra are longer and more parallel-sided than in any previously deseribed Australian species; they have two large spots, somewhat as in S. bimaculipennis, but that species is decidedly wider and more elliptic, and its legs and head are red. On several specimens the basal half of the prothorax is black, 
but on others the black does not extend to the sides, the spot on each elytron is median, of irregular shape, and extends across about five interstices.

Stenotarsus alternatus, n. sp.

Black; an obseure spot on each side of prothorax, four vittae on elytra, and elytral epipleurae more or less red. Moderately clothed with semi-erect, rusty hair.

Head with small punctures, a shallow depression between eyes. Antennae eomparatively long, elub stout, apical joint almost as long as two preceding combined. Prothorax with sides strongly rounded in front, apex almost semieireularly emarginate, sublateral striae deep, becoming foveate at base; with small but rather sharply defined punctures, becoming rather coarse and dense on sides. Elytra with rather strongly rounded sides, widest at about basal fourth; with rows of rather large punctures in feeble striae, the interstices with small but distinet punctures. Length, $3.25 \mathrm{~mm}$.

Hab.-New South Wales: Kiama (unique).

Structurally elose to $S$. arithmeticus, and to several other species, but red elytral markings longitudinal; the vittae commence at the base and terminate near the apex, they are on the third and seventh interstices, but the one on the seventh is interrupted on each elytron near the base; the spot on each side of the prothorax is distinct immediately behind the eye, but may be traced almost to the base; the tarsi and palpi are obscurely diluted with red.

Periptyctus bryophilus, n. sp.

Flavous; middle and hind angles of prothorax, seutellum, greater portion of elytra, middle and base of prosternum, part of abdomen, coxae and club, more or less deeply infuscated. Upper surface glabrous, under surface almost so.

Head with fairly dense and sharply defined punctures. Antennae rather long, first joint stout, second as long as first but much thinner, third-eighth small, ninth-eleventh forming a club. Prothorax at base searcely twice as wide as the median length, sides thickened and strongly rounded, apex about half the width of base and gently incurved to middle, base bisinuate, hind angles acute, convex along middle, concave towards each side; punctures sparse and inconspicuous. Scutellum widely transverse. Elytra slightly wider than prothorax, a subfoveate impression on each side of base; with rather large punctures; in places somewhat seriate in arrangement, but not in striae. Under surface with numerous rather small but sharply defined punctures, less conspicuous on chin-piece than elsewhere. Length, 2.25-2.5 mm.

Hab.-Tasmania: Mount Wellington (A. M. Lea).

A beautiful little species of which two specimens were obtained from moss. It is larger and wider than $P$. russulus, very differently coloured, sides of prothorax different, elytral punctures larger, ete.; from the description of $P$. eximius it differs considerably in colour and sculpture. On the larger specimen the dark parts of the prothorax are almost black, its elytra have the basal fifth, except for a spot half-way between the scutellum and each shoulder, and sides pale, enclosing a large shield-shaped space, and its abdomen has a large subtriangular dark space; on the smaller specimen the markings are less dark, and much less of the abdomen is infuscated. The joints of the club are flattened, and from one point of view appear searcely wider than the preceding joints, but from another point they appear almost thrice as wide. 


\section{Periptyctus latericollis, n. $\mathrm{sp}$.}

Red; head, scutellum and most of prothorax infuscated, apical half of antennae blackish, each shoulder with a flavous spot. Upper surface glabrous, under surface slightly pubescent.

Head with a small impression near each eye. Antennae moderately long, first joint stout, second slightly longer, and much thinner than first, nintheleventh forming a rather wide club. Prothorax along middle longer than width of apex, sides thickened, on basal half strongly raised and almost parallel, strongly narrowed and less elevated to apex, which is gently emarginate; punctures sparse and inconspicuous. Elytra wider than prothorax, sides moderately rounded, shoulders rather strongly raised; with rather sparse and small punctures, but in places seriate in arrangement. Prosternum with chin-piece subtriangularly advanced, a groove on each side of it. Length, $2.5 \mathrm{~mm}$.

Hab.-Queensland: Mount Tambourine (C. Wild). Unique.

Larger than $P$. russulus, with the sides of prothorax suddenly and strongly elevated in middle, and with the chin-piece more prominent, etc.; it differs in many respects from the description and figure of $P$. eximius. The hind angles of the prothorax are almost spiniform, and project obliquely outwards; its dise is deeply infuscated, with the sides, especially in front, paler; part of its under surface is also dark; the punctures of the under surface are rather sparse and small on the abdomen, rather large but sparse on sides of metasternum, and fairly dense and large on parts of the prosternum.

\section{IDIOPHYES VIRIDIS, n. sp.}

Dark metallic-green, with a coppery gloss; under surface, legs, antennae and palpi more or less castaneous. Upper surface moderately densely clothed with long, suberect pubescence, under surface and legs with much shorter and depressed pubescence.

Head rather wide; with dense, small, and (when not partially obscured by elothing) sharply defined punctures. Antennae moderately long, basal joint stout, about half as long again as second, second stouter and slightly longer than third, fourth and fifth slightly decreasing in length, sixth and seventh slightly shorter and wider than fifth, eighth-tenth forming a conspicuous club, eighth and ninth each about as long as first, but much wider, tenth about half as long again as ninth. Prothorax at base about thrice as wide as the median length, sides strongly rounded, apex much narrower than base, a conspicuous groove towards each side, becoming wider at base, a narrow impressed line very close to base; punctures crowded and sharply defined. Elytra strongly convex, sides subcontinuous with those of prothorax, a small tubercle towards each side near apex; with rows of fairly large punctures in rather shallow striae; interstices with small, dense punctures. Length, $2 \mathrm{~mm}$.

Hab.-Tasmania: Hobart (A. M. Lea).

A beautiful little species of which four specimens were obtained from moss. Structurally it is close to I. brevis, and the antennae are also ten-jointed; but the upper surface is green, with longer elothing, and the prothoracic punetures are much more conspicuous.

\section{IDIOPHYES DUBIUS, n. sp.}

Reddish-castaneous; legs, antennae and palpi somewhat paler. Not very densely clothed with moderately long, suberect setae or pubescence. 
Head with rather dense small punctures. Antennae moderately long, first joint stouter and slightly longer than second, second stouter and longer than third, fourth-eighth gradually decreasing in length, ninth somewhat longer and distinctly wider than eighth, tenth still longer and wider, eleventh slightly wider and about half as long again as tenth. Prothorax at base scarcely twice as wide as the median length, sides rather strongly rounded, and somewhat narrower in front than behind; with a deep, continuous stria near each side, and another one at base; punctures small but sharply defined. Elytra at base slightly wider than base of prothorax, widest at about basal third; with rows of rather large punetures, becoming somewhat larger and more irregular about base, and smaller posteriorly; epipleurae fairly wide at base, very narrow beyond middle, and disappearing before apex. Under surface with dense punctures, larger on metasternum and basal segment of abdomen than elsewhere, the latter about as long as three following segments combined, a small sixth segment traceable. Legs not very long; front coxae separated by a narrow keel. Length, 1.25-1.5 mm.

Hab.-Tasmania: Hobart (A. M. Lea).

At first glance this species appears to be a Mycetaea, but the third joint of its tarsi is minute and anchylosed to the fourth, instead of almost as conspicuous as the second. It was referred with doubt to Idiophyes, as the antennae are elevenjointed; it is decidedly narrower than $I$. brevis, the elytral epipleurae are narrower, and the elothing and punctures are different.

\section{IDIOPHYES HUMERALIS, n. sp.}

Castaneous; shoulders, elytral epipleurae, legs and palpi paler, club (its tip excepted) infuscated. Moderately clothed with semi-erect, pale pubescence, sparser and depressed on legs and under surface.

Head with two shallow interocular depressions; punctures indistinet. Antennae rather short, eleven-jointed, three apical joints forming a conspicuous club. Prothorax at base almost four times as wide as the median length, sides thickened, oblique, but rounded in front; a narrow deep stria near each side, closed posteriorly but open behind the eye, bounded internally by an acute ridge; apex incurved at sides but straight in middle, very finely margined, a narrow impression across base; with fairly numerous punctures towards sides, but sparse in middle. Scutellum small and widely transverse. Elytra short, slightly wider at base than prothorax, strongly rounded beyond middle, a rather deep impression at base near each shoulder, sides distinctly margined; with fairly large, sharply defined and numerous, but not crowded punctures; a feeble stria on each side of suture. Prosternum with a distinct median keel, which is bistriated between coxae. Length, $1.5 \mathrm{~mm}$.

Hab.-New South Wales: Sydney (A. M. Lea).

A short, strongly convex species, the pale shoulders rendered more conspicuous by the depression at the inner side of each. In general appearance nearer $I$. brevis than $I$. dubius, but the eleven-jointed antennae associate it with the latter. On parts of the under surface the punctures are dense and sharply defined, but they are much smaller in places; the abdomen appears to have a minute sixth segment, but it may be an extrusible one; the prothorax is almost glabrous in the middle. 


\section{CORYLOPHIDAE.}

Aphanocephalus potamophilus, n. sp.

Dull reddish-castaneous; legs, antennae and palpi paler, part of elytra infuscated. Rather densely clothed with pale, short, semi-erect pubescence.

Head with dense, partially concealed punctures. Prothorax almost four times as wide as the median length, sides strongly rounded and finely margined, apex gently incurved to middle and about half the width of base; with small, dense, partially concealed punctures. Elytra with outlines and margins continuous with those of prothorax; with small, dense, partially concealed punctures. Under surface with rather small but sharply defined punctures, smaller in middle of metasternum than elsewhere. Length, 2-2.25 mm.

Hab.-North Western Australia: Upper Ord River (R. Helms).

An oblong-elliptic species, obtained in abundance at the water's edge. It is larger, wider and with smaller and denser punctures than $A$. punctulatus; placed side by side the punctures on the elytra of the present species are only about half the size of those of that species. The infuscation of the elytra consists of a large, median spot, varying considerably in size, but apparently never sharply defined. Under a compound power the basal joint of the antennae appears fairly stout, third slightly longer than fourth, distinetly longer than second, and slightly shorter than first, seventh and eighth rather short, and ninth as a stout one-jointed club, about as long as the four preceding combined.

\section{ApHanocephalus pallidipennis, n. sp.}

Pale reddish-castaneous; legs, antennae (club excepted) and palpi somewhat paler, head and prothorax blackish or deeply infuscated, sides of the latter obscurely diluted with red. Densely clothed with short, pale, depressed pubescence. Length, $1.6 \mathrm{~mm}$.

Hab.-Queensland: Cairns (C. J. Wild), Little Mulgrave River (H. Hacker).

The description of the sculpture of the preceding species applies exactly to the present one, but the latter is much smaller, differently coloured and with different clothing; on the elytra the pubescence has a slightly mottled appearance, and from one direction on the right seems condensed so as to form a pale $\mathrm{S}$ (reversed on the left elytron). The size and shape are much as those of $A$. poropterus, but the elytra are reddish and with much less conspicuous punctures; the curious undulations of the clothing, to a certain extent, suggest the basal markings of that species.

\section{Aphanocephales quadrimaculatus, n. sp.}

Black or blackish, parts of appendages obscurely paler; elytra with four, fairly large, round, red spots. Clothed with very short, inconspicuous pubescence. Length, $2 \mathrm{~mm}$.

Hab.-Queensland: Hamilton (C. J. Wild).

Slightly more elliptic than $A$. potamophilus, with prothorax wider at apex and punctures less concealed by clothing; the elytral spots are placed as it marking the corners of a square: two at the basal third and two at the apical third; it is larger than A. quadrinotatus, and the spots are quite round, without showing a tendeney to become confluent; structurally it is nearer $A$. bimaculatus. One of the specimens has the whole of the under surface obseurely brownish. 


\section{$2 \mathrm{BHL}$ Biodiversity Heritage Library}

Lea, A. M. 1921. "Descriptions of new species of Australian Coleoptera. Part XVII." Proceedings of the Linnean Society of New South Wales 46, 351-369. https://doi.org/10.5962/bhl.part.14024.

View This Item Online: https://www.biodiversitylibrary.org/item/23930

DOI: https://doi.org/10.5962/bhl.part.14024

Permalink: https://www.biodiversitylibrary.org/partpdf/14024

\section{Holding Institution}

MBLWHOI Library

\section{Sponsored by}

MBLWHOI Library

\section{Copyright \& Reuse}

Copyright Status: NOT_IN_COPYRIGHT

This document was created from content at the Biodiversity Heritage Library, the world's largest open access digital library for biodiversity literature and archives. Visit BHL at https://www.biodiversitylibrary.org. 